\title{
IDEALIZATION OF THE REAL STIRLING CYCLE
}

\section{LIBOR ČERVNKA}

Czech Technical University in Prague, Vehicle Center of Sustainable Mobility, Technická 4, Prague 6, Czech Republic

E-mail: libor.cervenka@fs.cvut.cz

\section{ABSTRACT}

The paper presents a potential idealization of the real Stirling cycle. This idealization is performed by modifying the piston movement corresponding to the ideal Stirling cycle. The focus is on the cycle thermodynamics with respect to the indicated efficiency and indicated power. A detailed 1-D simulation model of a Stirling engine is used as a tool for this assessment. The model includes real non-zero volumes of heater, regenerator, cooler and connecting pipe. The model is created in the GT Power commercial simulation software.

\section{KEYWORDS: STIRLING CYCLE, I-D MATHEMATICAL MODEL, IDEAL PISTON MOVEMENT}

\section{SHRNUTí}

V tomto článku jsou prezentovány možnosti idealizace reálného Stirlingova oběhu. Tato idealizace spočivá v náhradě sinusového pohybu pístu daného klikovým mechanismem pohybem popisujícím změny ideálního Stirlingova oběhu. Článek popisuje vliv této změny na vnitřní termodynamiku oběhu, indikovanou účinnost a indikovaný výkon. Pro posouzení těchto změn je použit detailní 1-D matematický model Stirlingova motoru. Tento model zahrnuje reálné nenulové objemy ohřivače, regenerátoru, chladiče a spojovacích potrubí. Model je vytvořen v komerčním programu - GT Power.

\section{KLIČCOVÁ SLOVA: STIRLINGŮV OBĚH, I-D MATEMATICKÝ MODEL, IDEÁLNÍ POHYB PÍSTU}

\section{INTRODUCTION}

The continual efforts of humanity to build a machine capable of converting thermal energy into mechanical work more efficiently leads to the creation of new mechanisms that would be able to realize cycles with ideal reversible changes. One of these cycles is the Carnot cycle. This cycle can operate with the highest possible thermal efficiency for given temperature levels. The cycle consists of two isotherms and two isentropic changes. Thermal efficiency is dependent only on the ratio of maximum and minimum temperature (1).

$\eta_{t}=1-\frac{T_{\min }}{T_{\max }}$

The Stirling cycle with $100 \%$ regeneration of heat can work with the same thermal efficiency as the Carnot cycle. The Stirling cycle consists of two isotherms and two isochoric changes with heat regeneration. Heat transfer is realized (ideally) at the same temperatures. The advantage of using isochoric change is the much lower pressure peak than in the case of isentropic compression in the original Carnot cycle.
Thermal efficiency of a real Stirling engine is very low compared to the ideal cycle. This difference is due to the real irreversible thermal changes, real viscous gas and real geometry. Heat transfer must be realized by non-zero volumes of heat exchangers and regenerators. Sinusoidal piston motion is realized by the crankshaft mechanism. There aren't any other options that use real gas and heat exchangers in a real engine, but the theoretical possibility exists of achieving idealized piston movement. This article is focused on the influence of idealized movement of the piston on the thermal efficiency and indicated power of the Stirling cycle. It further explains why it isn't correct to compare the real cycle with the ideal Stirling cycle and why it is better to use a different cycle, the Pseudo Stirling cycle.

A mathematical model, based on the real Stirling engine presented in [1] is used as a tool for solving cycle thermodynamics. The model therefore includes non-zero volumes of regenerator, heater and cooler. Their sizes are the same as in the model with crankshaft mechanism created according to the measured prototype described in [1]. This is also due to the same heat transfer area and heat capacity of the regenerator. The engine 
is operated at a synchronous speed of $1500 \mathrm{~min}^{-1}$. Isothermal compression and expansion cannot be realized due to the nonzero volumes of heat exchangers and relatively high speed. The compression and expansion are in fact isentropic. Isochoric supply and heat dissipation are achieved by moving the working medium between a cold cylinder and a hot cylinder. This cycle is sometimes called a pseudo Stirling cycle. The mathematical model has been built using the GT-Power software. This software includes a solver of partial differential equations of gas dynamics for compressible flow. It takes into account mass, energy and momentum conservation as well as the irreversibility of compressible, non-stationary flow, and heat transfer between gas and walls. A 1-D discretization is used in the manifolds. A 0-D (time dependent only) solution of thermodynamic quantities is used for parts with variable displacement (e.g. cylinders). This more realistic but still idealized cycle will be compared to a highly idealized cycle to better identify the sources of discrepancies.

\section{THEORETICAL IDEALIZED CYCLES}

The ideal Stirling cycle consists of two workspaces interconnected through the regenerator. The working medium is an ideal inviscid gas (i.e., with constant thermal capacities and without pressure losses). The entire working medium is always located in a cold or a hot space, since no dead volumes are present. The principle is illustrated in Figure 1. A cold cylinder piston is at the bottom dead center (BDC). For the situation plotted, a hot cylinder piston is at the top dead center (TDC). All working medium is in the cold volume. The piston in the hot cylinder is standing and the piston in the cold cylinder is moving to the TDC and compresses the working medium. Heat is removed from the gas through the cold cylinder wall. Compression proceeds therefore at constant temperature.

This process is shown in the pressure volume diagram $(p-v)$ and temperature entropy diagram (T-s) in Figure 2 . The compression is plotted between states labelled 1 and 2. Both pistons move synchronously and the working medium is transferred through

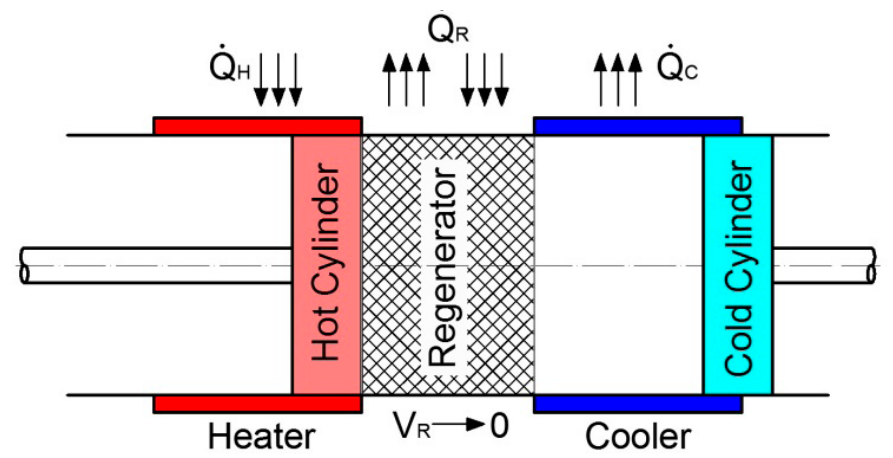

FIGURE 1: Schematic diagram of ideal Stirling engine. OBRÁZEK 1: Schéma idealizovaného Stirlingova motoru.
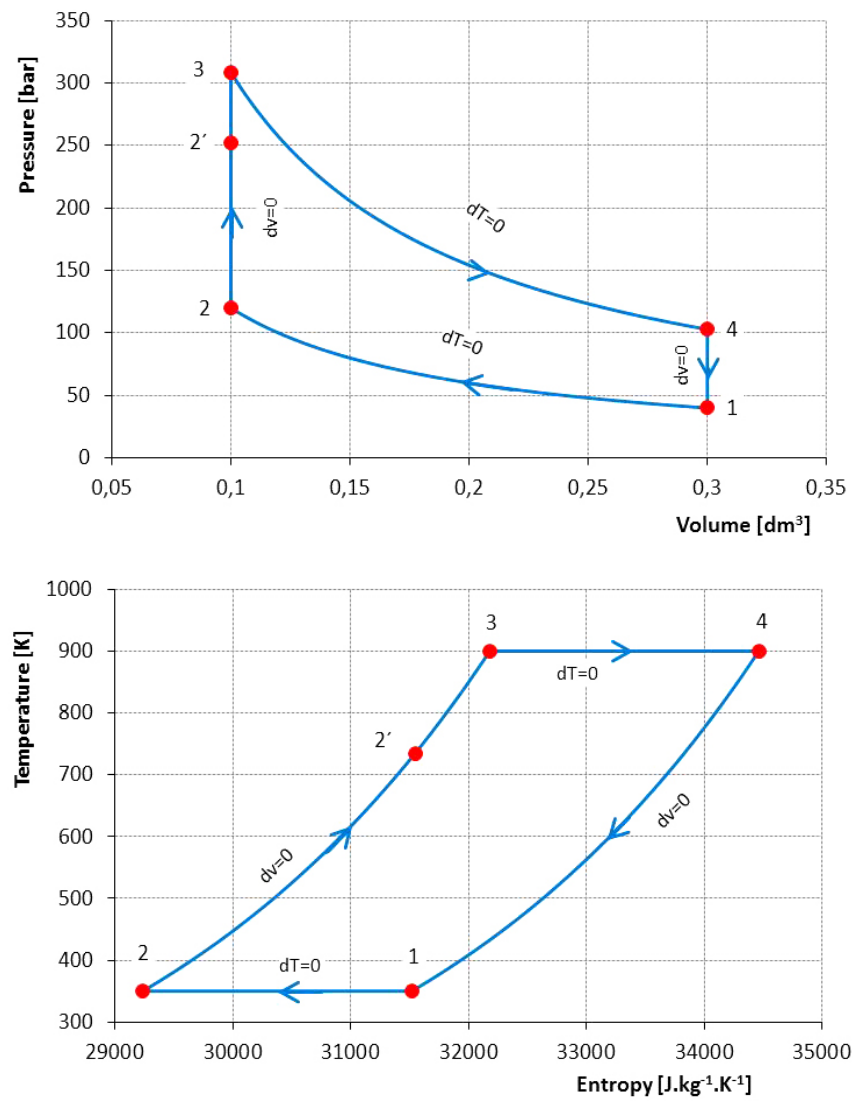

FIGURE 2: Pressure - volume and temperature - entropy diagrams of the ideal Stirling cycle.

OBRÁZEK 2: $\mathrm{p}-\mathrm{V}$ a T - s diagramy idealizovaného Stirlingova oběhu.

the regenerator from the cold space to the hot space. The regenerator volume is equal to zero in the ideal cycle. Heat, equal to that transferred to regenerator material during the previous reverse motion of both pistons, is transferred to the working medium from the regenerator walls. This change is presented in Figure 2 between the states 2 and 3. After this, the working medium expands in the hot cylinder. This expansion proceeds at constant temperature and the heat is supplied through the hot cylinder wall. It is shown in the p-v and T-s diagrams between states labelled 3 and 4 . The last change is the transfer of working medium back into the cold space. Both pistons move synchronously (change at constant volume). It is shown in Figure 2 between states 4 and 1 . In this change heat is accumulated in the regenerator material, as mentioned above. Thermal efficiency $\eta_{t}$ of the ideal Stirling cycle is given by Equation (2). Efficiency is defined as cycle work divided by heat supplied to the engine from the outside,

$\eta_{t}=\frac{(\kappa-1)(\tau-1) \ln \varepsilon}{(\tau-1)(1-\xi)+\tau(\kappa-1) \ln \varepsilon}$ 
where Poisson constant is labelled $\kappa$. Compression ratio $\varepsilon$ is given by the ratio of maximum $v_{1}$ to minimum $v_{2}$ volume Equation (3)

$$
\varepsilon=\frac{v_{1}}{v_{2}}=\frac{v_{4}}{v_{3}}
$$

Temperature ratio $\tau$ is defined by the ratio of $T_{\max }$ to $T_{\min }-$ Equation (4)

$$
\tau=\frac{T_{\max }}{T_{\min }}=\frac{T_{3}}{T_{1}}
$$

Regenerator efficiency $\xi$ is given by the ratio of heat supplied to the engine from the outside between the states labelled 2 and 2 ' to the maximum possible heat accumulated in a regenerator between states labelled 4 and 1 (state 2 has the same temperature as 1). This efficiency is given by Equation (5)

$\xi=\frac{T_{2^{I}}-T_{2}}{T_{4}-T_{2}}$

The thermal efficiency of the idealized Stirling cycle is given by Equation (1) only if the regeneration efficiency is $100 \%$. Efficiency reaches that of the Carnot cycle and depends only on minimum and maximum temperatures. Specific cycle work $w$ is given by Equation (6)

$w=c_{v}(\kappa-1) \cdot T_{\min } \cdot(\tau-1) \ln \varepsilon$

where $c_{v}$ is specific heat capacity of the working medium at constant volume.

The thermal efficiency of the ideal Stirling cycle in relation to compression ratio is shown in Figure 3. Efficiency is calculated for temperature ratio $\tau=2.57$ and Poisson constant $\kappa=1.4$. The various curves represent thermal efficiency as a function of regeneration efficiency.

Efficiency increases with compression ratio up to a maximum value (red line). This is valid for $100 \%$ regeneration efficiency. The thermal efficiency of the cycle is then the same as the Carnot cycle efficiency given by Equation (1). Specific work is represented by the dashed curve. It increases with increasing compression ratio.

Heat supply and cooling cannot be realized through the small surfaces of the cylinder wall alone. Therefore, a heater and a cooler must be placed between the hot and cold cylinder (Figure 4).

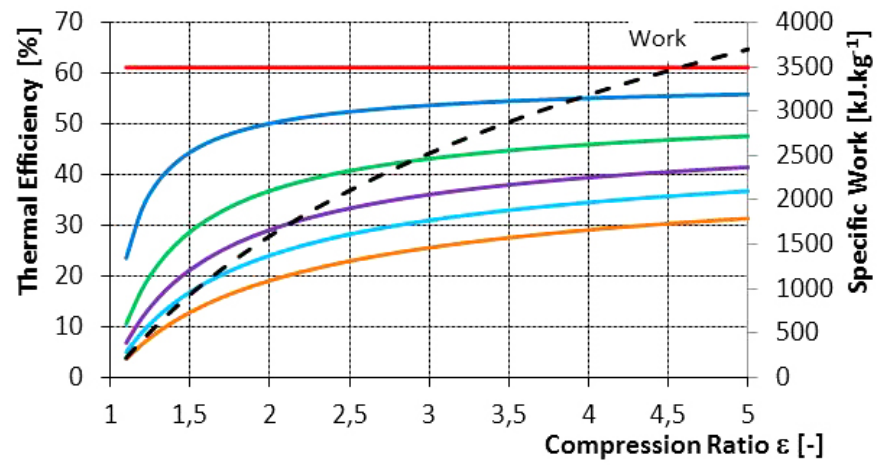

Regeneration Efficiency $-1-0,9-0,7-0,5-0,3-0$

FIGURE 3: Thermal efficiency of the ideal Stirling engine for various regeneration efficiencies and cycle specific work.

OBRÁZEK 3: Tepelná účinnost a měrná práce idealizovaného Stirlingova motoru pro různé účinnosti regenerace.

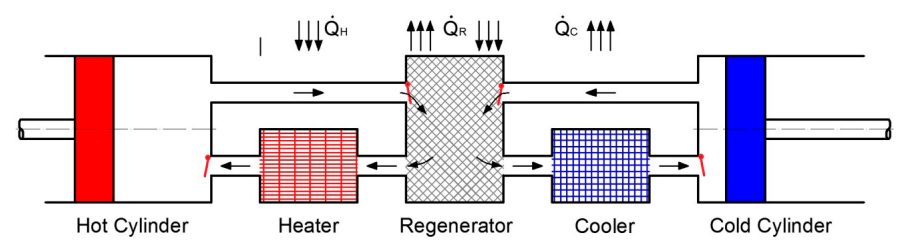

FIGURE 4: Schematic diagram of an ideal regenerative constant volume cycle with backflow valve.

OBRÁZEK 4: Schéma idealizovaného oběhu s přivodem a odvodem tepla při konstantním objemu opatřeného ventily k zabránění zpětného toku.

If a real high speed engine is used to increase the power simultaneously, heat transfer takes place during isochoric phases only. For this reason, isothermal changes cannot be realized. Compression and expansion are closer to isentropic ones. This cycle is called the ideal regenerative constant volume cycle. It does not use the same temperatures at the cooled and heated sides for regeneration of heat. Compression of working medium is isentropic. These states are labelled 1 and 2 in the $p$-v and T-s diagrams in Figure 5. The working medium is transferred from the cold cylinder into the hot cylinder at constant volume. It bypasses the cooler and flows through the regenerator and the heater to the hot space. This change is shown between states 2 and 3. Then the isentropic expansion occurs in the hot space between states 3 and 4 . The last change is a transfer of the working medium back into the cold spaces. Both pistons move synchronously and the change is at constant volume. It is shown between states 4 and 1 in Figure 5 . In this change working medium bypasses the heater and heat is accumulated in the regenerator.

Thermal efficiency $\eta_{t}$ of the ideal regenerative constant volume cycle is given by Equation (7) 

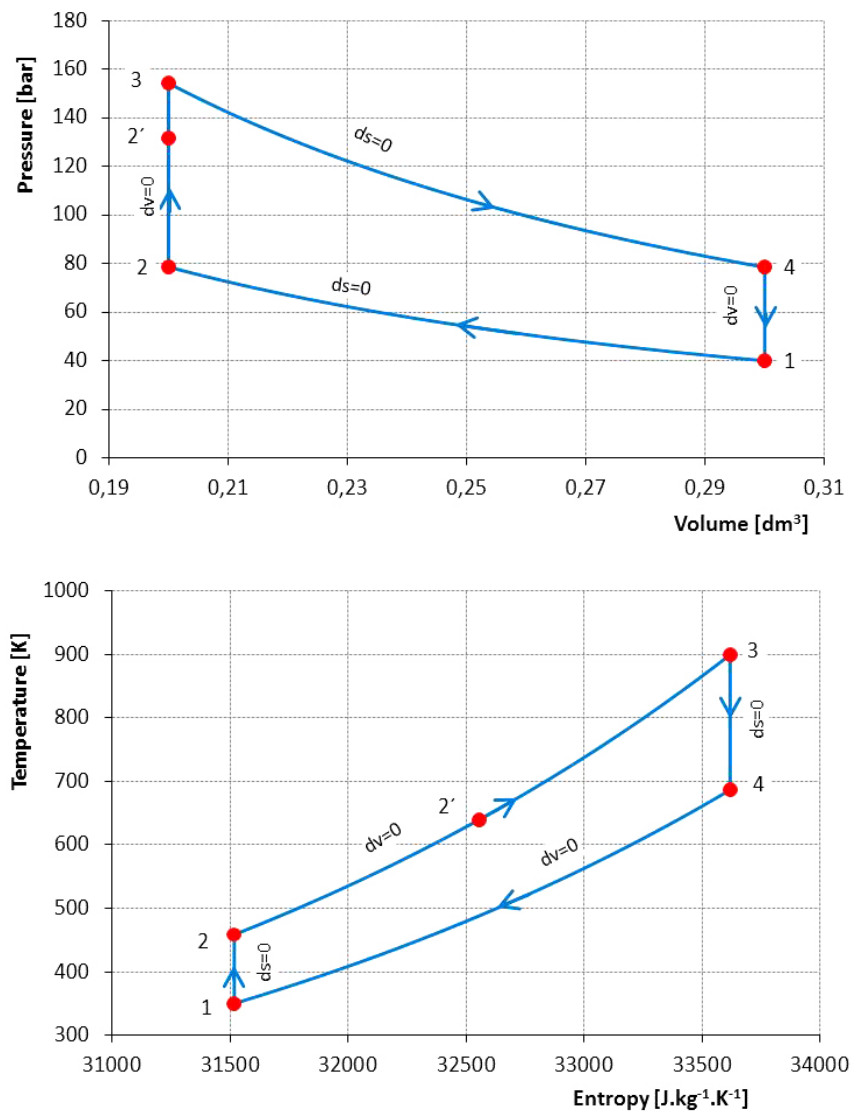

FIGURE 5: Pressure - volume and temperature - entropy diagrams of ideal regenerative constant volume cycle.

OBRÁZEK 5: $p-V$ a T - s diagramy idealizovaného oběhu $s$ prívodem a odvodem tepla prí konstantním objemu.

$\eta_{t}=\frac{\left(\tau-\varepsilon^{\kappa-1}\right)\left(1-\varepsilon^{1-\kappa}\right)}{\tau-\xi\left(\frac{\tau}{\varepsilon^{\kappa-1}}-\varepsilon^{\kappa-1}\right)-\varepsilon^{\kappa-1}}$

where the compression ratio $\varepsilon$ is defined by Equation (3), the temperature ratio $\tau$ is defined by Equation (4) and regenerator efficiency $\xi$ is given by the ratio of the heat supplied to the cycle between the states labelled 2 and 2 ' to the maximum possible heat accumulated in the regenerator between states labelled 4 and 2. Regenerator efficiency is given by Equation (5). Specific cycle work $w$ is given by Equation (8)

$w=c_{v} \cdot T_{1} \cdot\left[\left(\tau-\varepsilon^{\kappa-1}\right)\left(1-\varepsilon^{1-\kappa}\right)\right]$

The thermal efficiency of the ideal regenerative constant volume cycle with respect to the compression ratio is shown in Figure 6. Efficiency is calculated for temperature ratio $\tau=257$ and Poisson constant $\kappa=1.4$. The various curves represent thermal efficiency as a function of the

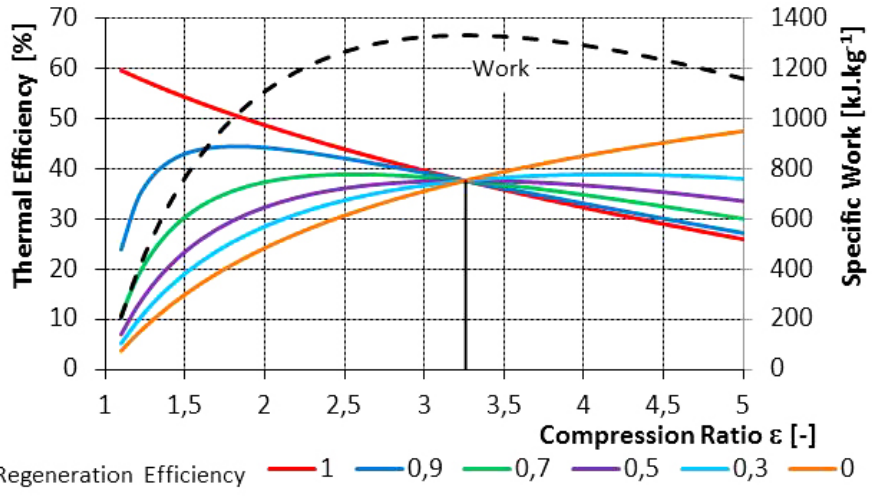

FIGURE 6: Thermal efficiency of the ideal regenerative constant volume cycle for various regeneration efficiencies and cycle specific work. OBRÁZEK 6: Tepelná účinnost a měrná práce idealizovaného oběhu s prívodem a odvodem tepla při konstantním objemu pro různé účinnosti regenerace.

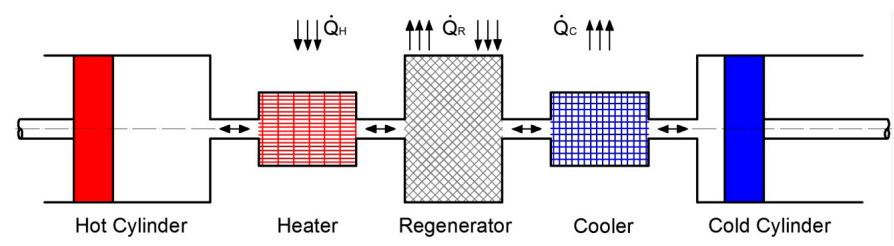

FIGURE 7: Schematic diagram of a pseudo Stirling engine. OBRÁZEK 7: Schéma pseudo Stirlingova motoru.

regeneration efficiency. The graph shows that there is an optimal compression ratio for maximum efficiency. All curves of efficiency intersect at a ratio of approximately 3.25. This is the point from which regeneration is not possible. The temperature after compression (point 2 in Figure 5 ) is higher than the temperature after expansion (point 4 in Figure 5). The orange line represents the cycle without regeneration (i.e. Otto cycle, which describes an idealized spark ignition internal combustion engine). The efficiency of this cycle increases with increasing compression ratio. The dashed curve represents the specific work. Work reaches a maximum and then decreases with further increase of compression ratio.

A variant without the bypass coolers and heaters is often used. The working medium flows through heat exchangers in both directions. This variant is shown schematically in Figure 7. As in the previous case, compression in the cold space is isentropic. It is shown between the states 1 and 2 in Figure 8 . Then the working medium flows through the cooler at constant volume. The working medium is first cooled to the temperature labelled 2T. Temperature $2 \mathrm{~T}$ is the same as in the state before compression 1. Flow continues through the regenerator and the heater up to the state 3 at constant volume. 

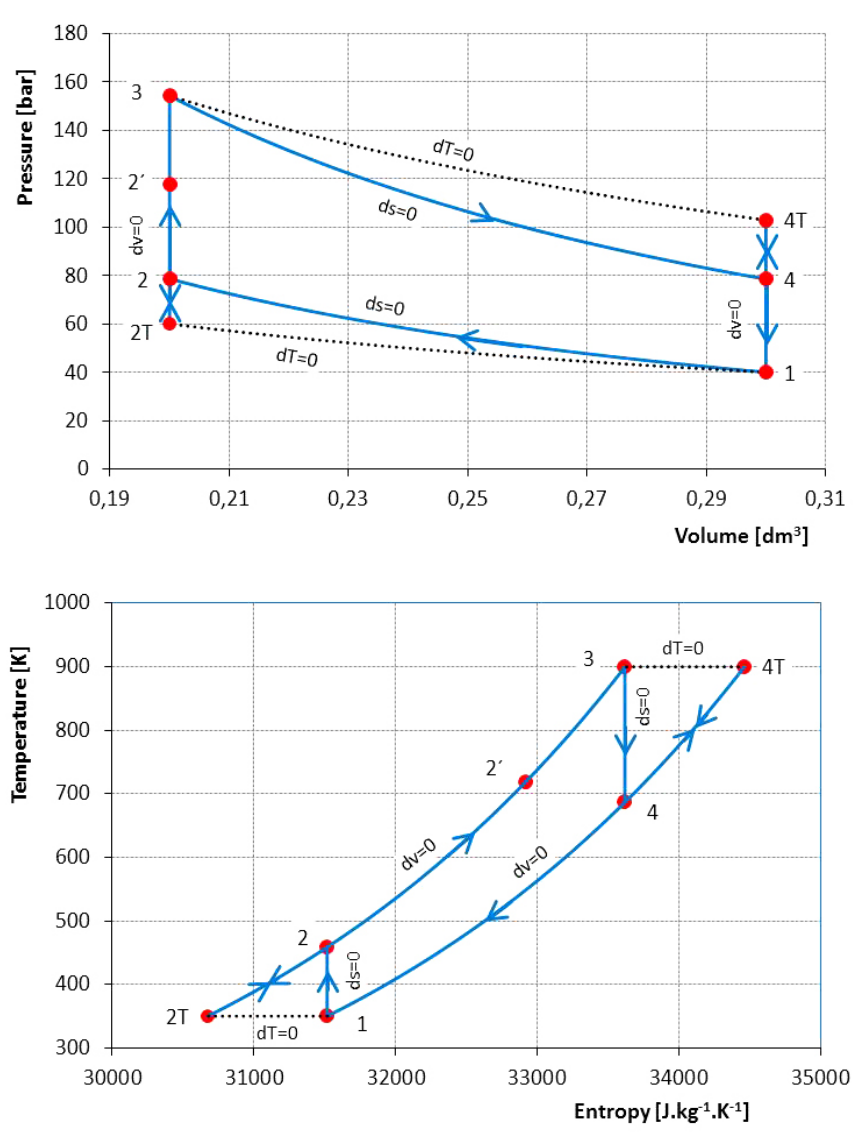

FIGURE 8: Pressure - volume and temperature - entropy diagrams of a pseudo Stirling cycle.

OBRÁZEK 8: $\mathrm{p}-\mathrm{V}$ a T - s diagramy pseudo Stirlingova oběhu.

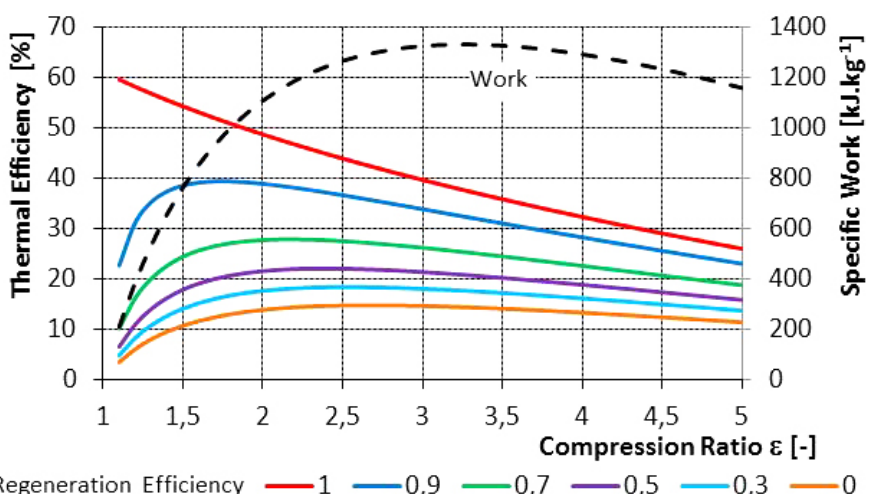

FIGURE 9: Thermal efficiency of a pseudo Stirling engine for various regeneration efficiencies and cycle specific work.

OBRÁZEK 9: Tepelná účinnost a měrná práce pseudo Stirlingova motoru pro různé účinnosti regenerace.

Expansion of working fluid is isentropic in the hot space at state 4. Then, the working medium flows back through the heater where it is heated to the temperature $4 \mathrm{~T}$. Then, the working medium is transferred back through the regenerator and cooler into the cold space. Both pistons move synchronously and the change is at constant volume. It is shown between states $4 \mathrm{~T}$ and 1 in Figure 8 . In this change heat is accumulated in the regenerator and is higher than in the previous case.

Thermal efficiency ht of the pseudo Stirling cycle is given by Equation (9)

$$
\eta_{t}=\frac{\left(\tau-\varepsilon^{\kappa-1}\right)\left(1-\varepsilon^{1-\kappa}\right)}{\tau\left(1-\frac{1}{\varepsilon^{\kappa-1}}\right)+(\tau-\xi(\tau-1)-1)}
$$

where the compression ratio $\varepsilon$ is given by Equation (3), the temperature ratio $\tau$ is given by Equation (4) and regenerator efficiency $\xi$ is given by the ratio of the heat supplied to the cycle between the states labelled $2 \mathrm{~T}$ and 2 ' to the maximum possible heat accumulated to the regenerator between states labelled $4 \mathrm{~T}$ and 1 (2T has the same temperature as 1 ). Regenerator efficiency is given by Equation (10)

$\xi=\frac{T_{2^{I}}-T_{2 T}}{T_{4 T}-T_{2 T}}$

Specific cycle work $w$ is given by Equation (10) as in the previous case.

The thermal efficiency of the pseudo Stirling cycle, as a function of compression ratio, is shown in Figure 9. Efficiency is calculated for temperature ratio $\tau=2.57$ and Poisson constant $\kappa=1.4$. The various curves represent thermal efficiency against the regeneration efficiency. There is an optimal compression ratio for maximum efficiency. The dashed curve represents the specific work. Work has a maximum and then decreases with increasing compression ratio.

This part of paper explained why the pseudo Stirling cycle is better for description of the real Stirling cycle.

\section{REAL STIRLING ENGINE CYCLE}

The schematic diagram of a real cycle (Figure 10) is similar to the pseudo Stirling engine (Figure 7), except it has non-zero volumes of regenerator, heater, cooling and connecting pipes. A buffer is connected below the pistons and is over pressurized with working medium. It is used to decrease bearing load. Therefore, the working medium is not located in the hot or cold space only. It is spread over the total volume (sum of all volumes) depending on the actual volumes and the temperatures in the individual sections. Heat supply and cooling is only in the part of the working medium. Another difference is the use of real viscous gas with good aerodynamic properties (usually helium or hydrogen). A major difference is the use of a crank mechanism. Therefore, the piston movements are approximately sinusoidal. 


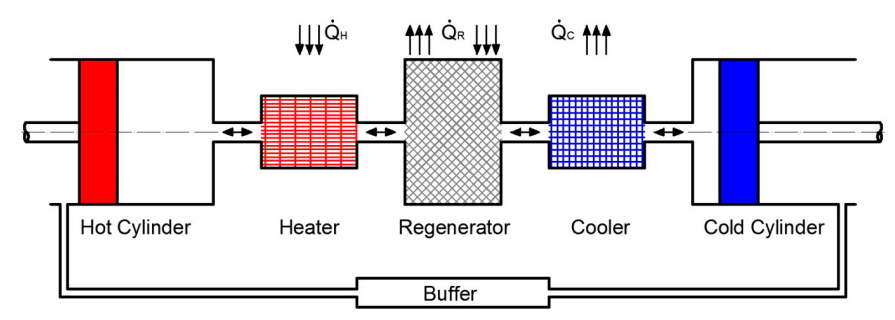

FIGURE 10: Schematic diagram of a real Stirling engine. OBRÁZEK 10: Schéma reálného Stirlingova motoru.

Isothermic compression and expansion cannot be achieved due to non-zero volumes of the heat exchangers and high engine speed in the real case. Ideal movement of the Stirling engine is only one way to approach the theoretical idealized cycle. This mechanism of ideal movement does not exist, but we can achieve it in the mathematical model.

This is why the pseudo Stirling cycle can be used as a more realistic but still idealized benchmark. For this case, piston movement tailored to the sequence of changes should be used. The following simulations were focused on such a movement, although a gear realizing it is not yet known.

The results have been compared to experimental outcomes of a Stirling engine prototype (alpha modification) with standard sinusoidal piston movement. The idealized engine had the same thermal parameters (except for cylinder volumes), but piston motion is close to the ideal motion pattern (Figure 12 green and yellow line) smoothed by Fourier polynomial representation. With the aim of achieving the same compression ratio in the realized prototype and idealized engine, the cylinder volumes of the idealized engine had to be changed, but the maximum sum of both volumes was kept at the same level as the prototype. This resulted in the re-designing of both cylinders, leading to a significant increase in individual volumes and to transport of more gas through all heat exchangers using higher velocities (shorter time of piston movement). At the end, pressure losses at heat exchangers are increased significantly, which can be shown by the individual pressure - volume diagrams in Figure 15, and is taken into account by integrals of work in Figure 15 (orange closed area). This important fact is not visible if the pressure - total volume diagram is used, Figure 15 (green and purple closed area). Moreover, this diagram is much narrower than the ideal one.

The mathematical model of the engine realized as a prototype was presented in [1] and [3]. The model was calibrated with data measured on the prototype. The new mathematical model of the Stirling engine with idealized piston motion is based on a model with real dimensions of the individual parts. The main change is changing the sinusoidal movement of pistons to the ideal Stirling engine piston movement.

The prototype engine is realized as an alpha modification. This means two separate cylinders (hot and cold) connected through a cooler, regenerator and heater. The displacement of each cylinder is $183 \mathrm{~cm}^{3}$. Cooler wall temperature is $350 \mathrm{~K}$ and heater wall temperature is $900 \mathrm{~K}$. The regenerator is made of steel. Engine speed is $1500 \mathrm{~min}^{-1}$. Working medium is helium. Nonzero volumes of heater $V_{h^{\prime}}$ regenerator $V_{r}$ and cooler $V_{c}$ with heat transfer area and heat capacity of the regenerator are shown in Figure 10.

\section{KINEMATICS MODIFICATION}

The original kinematics of the piston is nearly a sinusoidal motion determined using the full crank mechanism. Figure 11 shows strokes (volume change) of hot piston (full red line) and cool piston (full blue line). The workspace is formed between the hot and cold pistons. Therefore, the grey area represents the total stroke (total volume change).

The stroke of the idealized Stirling engine is shown in Figure 11 as dashed lines. The red dashed line represents the stroke of an idealized hot piston and the blue dashed line the stroke of the idealized cold piston. The orange area between these lines shows the idealized total stroke. Isochoric changes are shown between $-135^{\circ}$ crank angle (CA) and $-45^{\circ} \mathrm{CA}$, and between $45^{\circ} \mathrm{CA}$ and $135^{\circ} \mathrm{CA}$.

Compression ratio, minimum and maximum total volumes are not the same when idealized stroke is used with the same maximum value of hot and cold cylinders as shown in Figure 11 . The stroke must be increased from the original $45 \mathrm{~mm}$ to $72 \mathrm{~mm}$ to keep the same minimum and maximum stroke as shown in Figure 12 by the dashed lines. To achieve the same compression ratio, the cold cylinder volume has to be reduced. That means a larger cold cylinder volume change when the hot cylinder volume is at a minimum (i.e. between $-45^{\circ} \mathrm{CA}$ and $45^{\circ} \mathrm{CA}$ ).

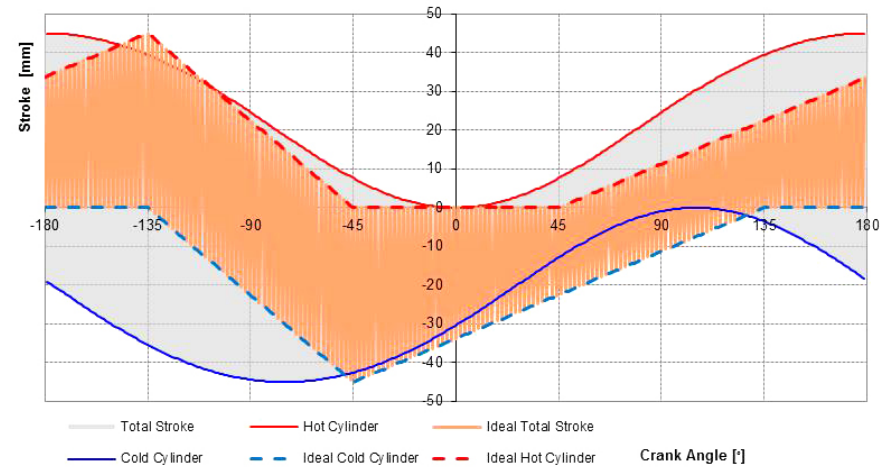

FIGURE 11: Hot and cold piston stroke and total stroke of the original and idealized kinematics.

OBRÁZEK 11: Průběh zdvihu horkého a studeného pístu a celkový zdvih původní a idealizované kinematiky. 


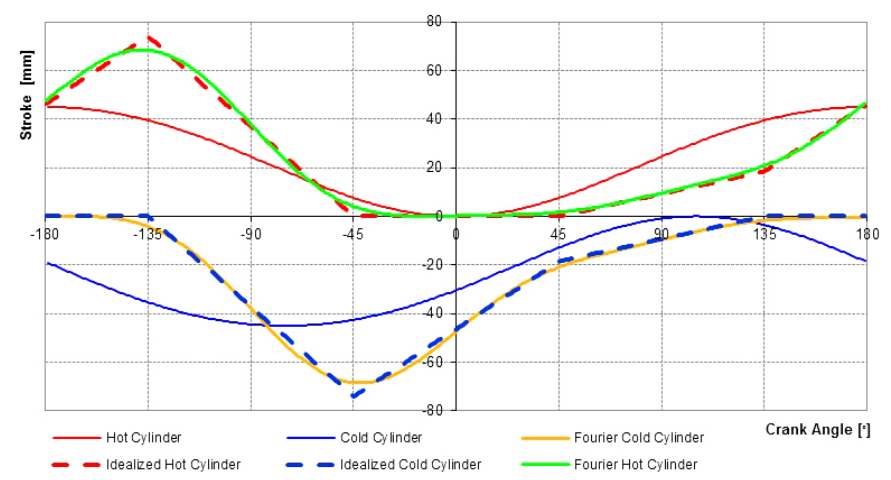

FIGURE 12: Stroke of the hot and the cold pistons replaced by Fourier polynomial used for modified kinematics.

OBRÁZEK 12: Průběh náhrady zdvihu horkého a studeného pístu

Fourierovým polynomem, který je použit v modifikované kinematice.

For this reason, the line representing the stroke of the cold piston changes gradient at $45^{\circ} \mathrm{CA}$. A different stroke gradient is exhibited between $45^{\circ} \mathrm{CA}$ and $135^{\circ} \mathrm{CA}$ for constant volume change. The same also occurs on the expansion side.

A Fourier polynomial is used in the mathematical model to replace the idealized discontinuous stroke and remove pressure oscillations close to an abrupt change in acceleration. Using 3 harmonic components the stroke is very close to the original straight line (Figure 12).

\section{RESULTS}

A comparison of both variants has been carried out by evaluation of both thermal efficiency and indicated power. Cycle work is computed by (12) and represented as the inner area of $\mathrm{pV}$ diagrams.

$d W=p \cdot d V$

In the most idealized case, assuming an ideal gas with zero pressure drop, cycle work calculation will be simplified from Equation (13) into Equation (14). The real work obtained in the hot cylinder $W_{h}$ is shown in Figure 13 as a red closed area. The work supplied in the cold cylinder $W_{c}$ is depicted as a blue closed area. The total cycle work $W$ is given as a sum of $W_{h}$ and $W_{c}$ with correct signs. Total work can also be calculated from the total volume and the work needed to overcome the pressure drop as shown in Equation (13).

$$
\begin{aligned}
& W=W_{h}+W_{c}=\oint_{h} p_{h} \cdot d V_{h}+\oint_{c} p_{c} \cdot d V_{c}=\oint_{h} p_{h} \cdot d V_{h}+ \\
& +\oint_{c}\left(p_{h}+\Delta p\right) \cdot d V_{c}=\oint_{h+c} p_{h} \cdot\left(d V_{h}+d V_{c}\right)+\oint_{c} \Delta p \cdot d V_{c}
\end{aligned}
$$

The total work $W$ is not determined from the common pressure multiplied by the sum of volumes only. The lost work required for transport of the working medium from the cold compression side to the hot expansion side and vice versa has to be taken into account. This work is expressed as pressure drop $\Delta \mathrm{p}$.

$W=\oint_{h+c} p \cdot\left(d V_{h}+d V_{c}\right)$

Work computed from total stroke and pressure in hot cylinder is shown in Figure 13 in green. The purple trace represents work computed from total stroke and pressure in the cold cylinder. Work overcoming the pressure drop seems to be small in

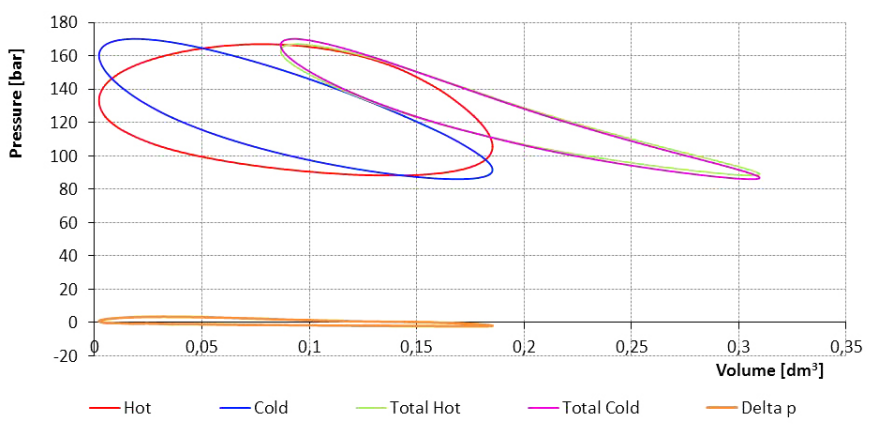

FIGURE 13: $p-V$ diagram of the hot (Hot - red line) and the cold (Cold - Blue line) cylinder and $p-V$ diagram of total volume and pressure in the hot cylinder (Total Hot - green line) and $p-V$ diagram of total volume and pressure in the cold cylinder (Total Cold - purple line) and $p-V$ diagram of work to overcome the pressure drop (Delta $p$ - orange line) for original sinusoidal kinematics.

OBRÁZEK 13: $p-V$ diagram horkého (Hot - červená čára) a studeného (Cold - modrá čára) válce a $\mathrm{p}-\mathrm{V}$ diagram celkového objemu a tlaku $v$ horkém válci (Total Hot - zelená čára) a $p-V$ diagram celkového objemu a tlaku ve studeném válci (Total Cold - fialová čára) a p V diagram práce pro překonání tlakových ztrát (Delta $p$ - oranžová čára) pro původní kinematiku.

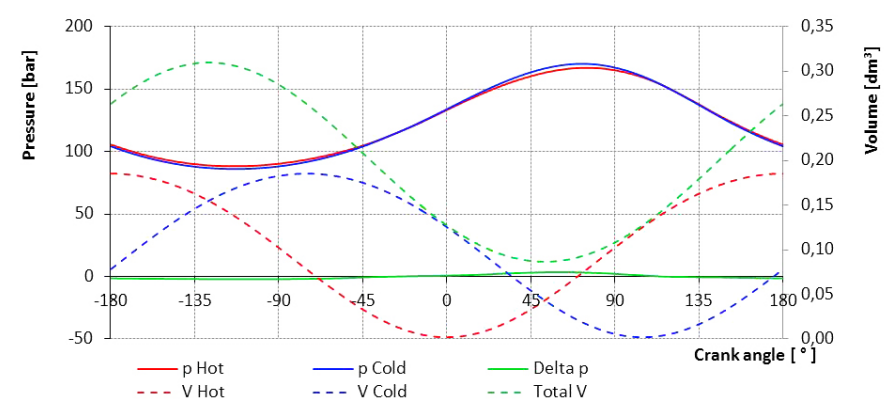

FIGURE 14: Pressure in the hot cylinder ( $p$ Hot), pressure in the cold cylinder ( $p$ Cold) and pressure drop (Delta $p$ ) depending on the crank angle original sinusoidal kinematics. Volume traces are shown for illustration only.

OBRÁZEK 14: Závislost tlaku horkého válce ( $\mathrm{p} \mathrm{Hot),} \mathrm{tlaku} \mathrm{studeného} \mathrm{válce}$ ( $p$ Cold) a tlakové ztráty (Delta $p$ ) na úhlu natočení klikového hř́dele pro původní kinematiku. Průběhy objemů jsou zobrazeny pro ilustraci. 
comparison with these two lines, but work to overcome pressure drop is multiplied by the large volume of the cold cylinder (13). In Figure 13 it is shown as an orange closed area.

In Figure 14 the volume and pressure traces, as a function of crank angle, are shown. The greatest pressure difference occurs simultaneously with the largest volume changes, which is evident from the pressure lines (i.e. volumes of hot and cold cylinders while the total volume shows the smallest change). Work overcoming the pressure drop for moving the working medium is calculated from the change of cold cylinder volume. The same graphs, but for the modified kinematics, are shown in subsequent figures. The Color marking is the same as in the previous case. Isochoric change is evident on the graph for

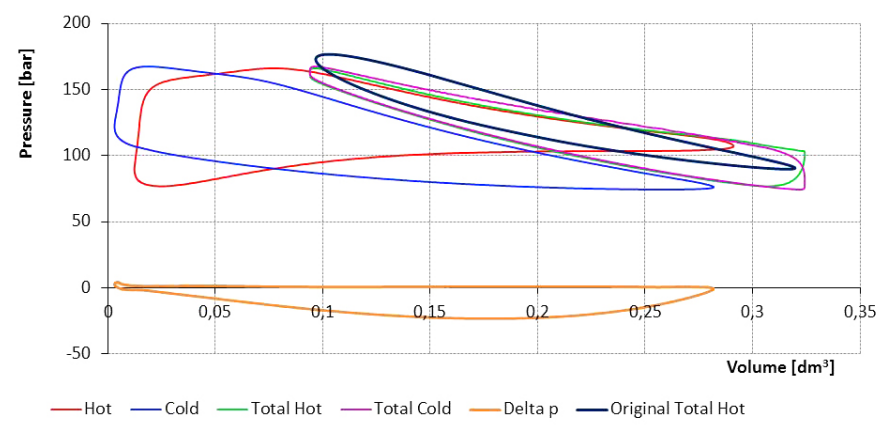

FIGURE 15: $p-V$ diagram of the hot (Hot - red line) and the cold (Cold - Blue line) cylinder and $p-V$ diagram of total volume and pressure in the hot cylinder (Total Hot - green line) and $p-V$ diagram of total volume and pressure in the cold cylinder (Total Cold - purple line) and $p-V$ diagram of work to overcome the pressure drop (Delta $p$ - orange line) for modified kinematics.

OBRÁZEK 15: $\mathrm{p}-\mathrm{V}$ diagram horkého (Hot - červená čára) a studeného (Cold - modrá čára) válce a $p-V$ diagram celkového objemu a tlaku $v$ horkém válci (Total Hot - zelená čára) a $\mathrm{p}-\mathrm{V}$ diagram celkového objemu a tlaku ve studeném válci (Total Cold - fialová čára) a $p$ V diagram práce pro překonání tlakových ztrát (Delta $\mathrm{p}$ - oranžová čára) pro modifikovanou kinematiku.

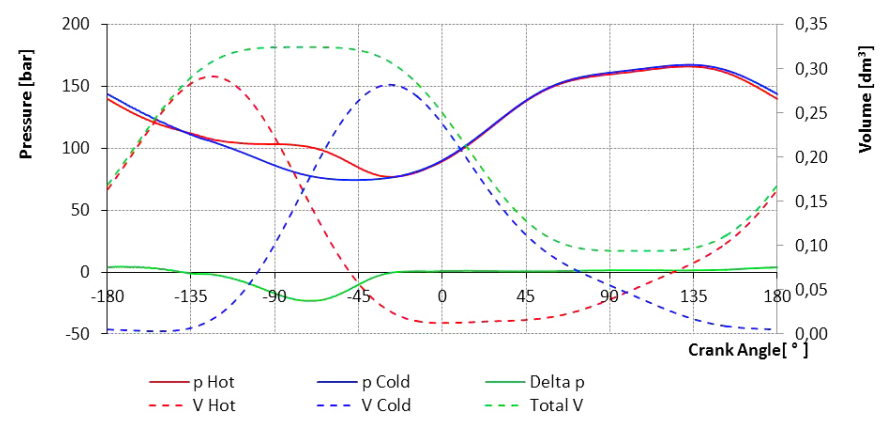

FIGURE 16: Pressure in the hot cylinder ( $p$ Hot), pressure in the cold cylinder ( $p$ Cold) and pressure drop (Delta $p$ ) depending on the crank angle modified kinematics. Volume traces are shown for illustration only. OBRÁZEK 16: Závislost tlaku horkého válce ( $\mathrm{p}$ Hot), tlaku studeného válce ( $p$ Cold) a tlakové ztráty (Delta $p$ ) na úhlu natočení klikového hřídele pro modifikovanou kinematiku. Průběhy objemů jsou zobrazeny pro ilustraci.

\begin{tabular}{|lccc|}
\hline & $\begin{array}{c}\text { Original } \\
\text { kinematics }\end{array}$ & $\begin{array}{c}\text { Modified } \\
\text { kinematics }\end{array}$ & \\
\hline Indicated power & 8.51 & 1.54 & {$[\mathrm{~kW}]$} \\
\hline Indicated efficiency & 27.15 & 4.07 & {$[\%]$} \\
\hline Hot cylinder power & 26.75 & 31.04 & {$[\mathrm{~kW}]$} \\
\hline Cold cylinder power & -17.90 & -28.47 & {$[\mathrm{~kW}]$} \\
\hline Power of total vol. hot press. & 10.25 & 13.81 & {$[\mathrm{~kW}]$} \\
\hline Power of total vol. cold press. & 10.33 & 14.78 & {$[\mathrm{~kW}]$} \\
\hline Power to overcome pressure drop & -1.40 & -11.24 & {$[\mathrm{~kW}]$}
\end{tabular}

TABLE 1: Performance parameters original and modified kinematics. TABULKA 1: Výkonové parametry původní a modifikované kinematiky.

the total volume. A big deference between this graph and the idealized Stirling cycle is obvious. The low isochoric change on the expansion side (minimum volume) is notable. It is caused by the supply of heat only to part of the working medium (only to the volume in a heater). Approximately the same pressure applies over the whole volume, but temperature varies from the minimum at the compression side to the maximum at the expansion side. Density of the working medium must be distributed from the maximum on the compression side to minimum on the expansion side. For this reason the heat is supplied into the smaller mass quantities to the expansion side. This is why pressure difference during isochoric change on the expansion side is lower than the pressure difference during isochoric change on the compression side in the idealized cycle. The original version of the $\mathrm{p}-\mathrm{V}$ diagram of total volume is shown for comparison. Total volume of work is higher in comparison with the original variant. However, the cycle work is lower due to the significantly increased work to overcome the pressure drop. This work is shown again as the orange closed area in Figure 15. In Figure 16 the reason for the rapid increase in pressure drop is visualized.

From the pressure traces it is evident that the greatest difference occurs at the fastest change of the particular volumes (i.e. volumes of hot and cold cylinders when total volume is constant). There is one essential difference in comparison with the original variant. In modified kinematics the piston is motionless during $1 / 4$ of the cycle duration. Transport of the working substance must be twice as fast in comparison with the original kinematics. With the same dimensions of regenerator, cooler and heater as [1] the increase in the pressure drop is significant. It is clearly visible in Figure 16 between $-135^{\circ} \mathrm{CA}$ and $-45^{\circ} \mathrm{CA}$. This problem can be eliminated by a large flow cross section. Then the heat exchanger must be shorter to keep the same volume. Sufficient heat transport need not be guaranteed in such exchangers. 
In Table 1 the numerical values for work (areas) are shown in terms of powers given by Equation (1). Indicated power is total power of cycle i.e. the sum of Hot cylinder power and Cold cylinder power. Indicated efficiency is cycle thermal efficiency given by dividing Indicated power by heat supply in the heat exchanger. Power given by total volume and pressure on the hot side is labelled Power of total vol. hot press. Power given by total volume and pressure on the cold side is labelled Power of total vol. cold press. These two values are similar, but they do not describe the total power of the cycle. From this value the Power to overcome the pressure drop has to be deducted. The powers for moving the working medium under the pistons and in the buffer are not included in the graphs and table for simplicity. This causes slight differences in values in Table 1.

\section{CONCLUSION}

It is evident that the use of idealized kinematics does not necessarily improve the cycle thermal efficiency. A significant decrease in the indicated power of the cycle from $8.51 \mathrm{~kW}$ to $1.54 \mathrm{~kW}$ is shown in Table 1. This is due to the increased power to overcome the pressure drop. For this reason the thermal efficiency of the cycle also decreases rapidly. A pressure drop is generated by the flow through the regenerator, cooler and heater when real gas is used. This pressure drop can be eliminated by using a larger cross-sectional area i.e. greater number of tubes. They must be shorter to keep the same volume. Sufficient heat flow may not be guaranteed in the exchangers.

\section{REFERENCES}

[1] ČERVENKA, L.: Mathematical Model of Real Stirling Engine. XLIV. International Scientific Conference of the Czech and Slovak University Departments and Institutions Dealing with the Research of Internal Combustion Engines \&\#8211; KOKA 2013. Brno: Mendelova univerzita v Brně, 2013, p. 98-107. ISBN 978-80-7375-801-1.

[2] VÁVRA, J., ČERVENKA, L., TAKÁTS, M., BROŽ, J.: Mathematical Model of a Real Stirling Engine Calibrated by Experiments. In: Mecca online - Journal of Middle European Construction and Design of Cars [online]. 2013, vol. 11, no. 2, p. 12-21. Internet: http://www.degruyter. com/view/j/mecdc.2013.11.issue-2/mecdc-2013-0008/ mecdc-2013-0008.xml. ISSN 1804-9338.

[3] VÁVRA, J., ČERVENKA, L., TAKÁTS, M., J.: Mathematical Model of a Real Stirling Engine Calibrated by Experiments. ISEC 2014 - $16^{\text {th }}$ International Stirling Engine Conference. Spain Bilbao, September 2014, ISSN 2409-0387

[4] VÁVRA, J., ČERVENKA, L., TAKÁTS, M., BROŽ, J.: Mathematical Model of a Real Stirling Engine Calibrated by Experiments. ASME 2014 International Engineering Congress and Exposition, Volume 8A, Canada Montreal, November 2014, ISSN 978-0-7918-4655-2

\section{ACKNOWLEDGEMENT}

This research has been realized using the support of Technological Agency, Czech Republic, programme Centres of Competence, project \# TE01020020 Josef Božek Competence Centre for Automotive Industry.

Technological support was provided by EU Regional Development Fund in OP R\&D for Innovations (OP VaVpl) and Ministry for Education, Czech Republic, project \# CZ.1.05/2.1.00/03.0125 Acquisition of Technology for Vehicle Center of Sustainable Mobility. 